\title{
19 \\ Deadly weapons: backed microliths from Narrabeen, New South Wales
}

\author{
Richard Fullagar ${ }^{1}$, Josephine McDonald ${ }^{2}$, Judith Field ${ }^{3}$ and Denise Donlon ${ }^{4}$ \\ 1. Scarp Archaeology \\ 25 Balfour Road, Austinmer NSW 2515 Australia \\ Email: richard.fullagar@scarp.com.au \\ 2. Jo McDonald Cultural Heritage Management and \\ Research School of Humanities, Australian National University \\ 77 Justin St., Lilyfield, NSW 2040 Australia \\ 3. Australian Key Centre for Microscopy and Microanalysis F09 and \\ School of Philosophical and Historical Inquiry \\ The University of Sydney, NSW 2006 Australia \\ 4. Department of Anatomy and Histology \\ The University of Sydney, NSW 2006 Australia
}

\begin{abstract}
A recently excavated skeleton dated to 3677 cal BP provides an extraordinary opportunity to determine the function of its associated backed artefacts. Seventeen stone artefacts were recovered during salvage excavation of an adult male Aboriginal skeleton from a sand dune in Narrabeen, a coastal suburb of Sydney. The skeletal and artefact evidence indicate death by spearing. Three artefacts were refitted, and, of the 14 near complete artifacts, 12 have been clearly backed. One backed artefact was found lodged between the L2 and L3 vertebrae with unhealed wounds, indicating spear penetration near the left hip. Other backed artefacts were found adjacent to or lodged in vertebrae suggesting two spears had penetrated from the back. Breakage and use-wear on most artefacts indicate use as barbs or 'lacerators'. In this study, we describe the use-wear and suggest possible hafting arrangements of these backed microliths, which probably functioned as piercing, cutting and lacerating elements of spears and knives.
\end{abstract}

\section{KEYWORDS}

use-wear, residues, backed artefacts, microliths, spears, knives

\section{INTRODUCTION}

A recently excavated skeleton dated to 3677 cal BP provides an extraordinary opportunity to determine the function of its associated backed artefacts (Figure 1). Seventeen stone artefacts (Figures 2 - 4; Table 1) were recovered during salvage excavation of an adult male Aboriginal skeleton, exposed during cable installations in a sand dune, $1.5 \mathrm{~m}$ below the present ground level in Narrabeen, a coastal suburb of Sydney (McDonald et al. 2007). The skeletal and artefact evidence indicates death by spearing.

A backed artefact (OON1; Figure 2) found during excavation was lodged between the second and third lumbar vertebrae in the region of the intervertebral disc, with major unhealed 


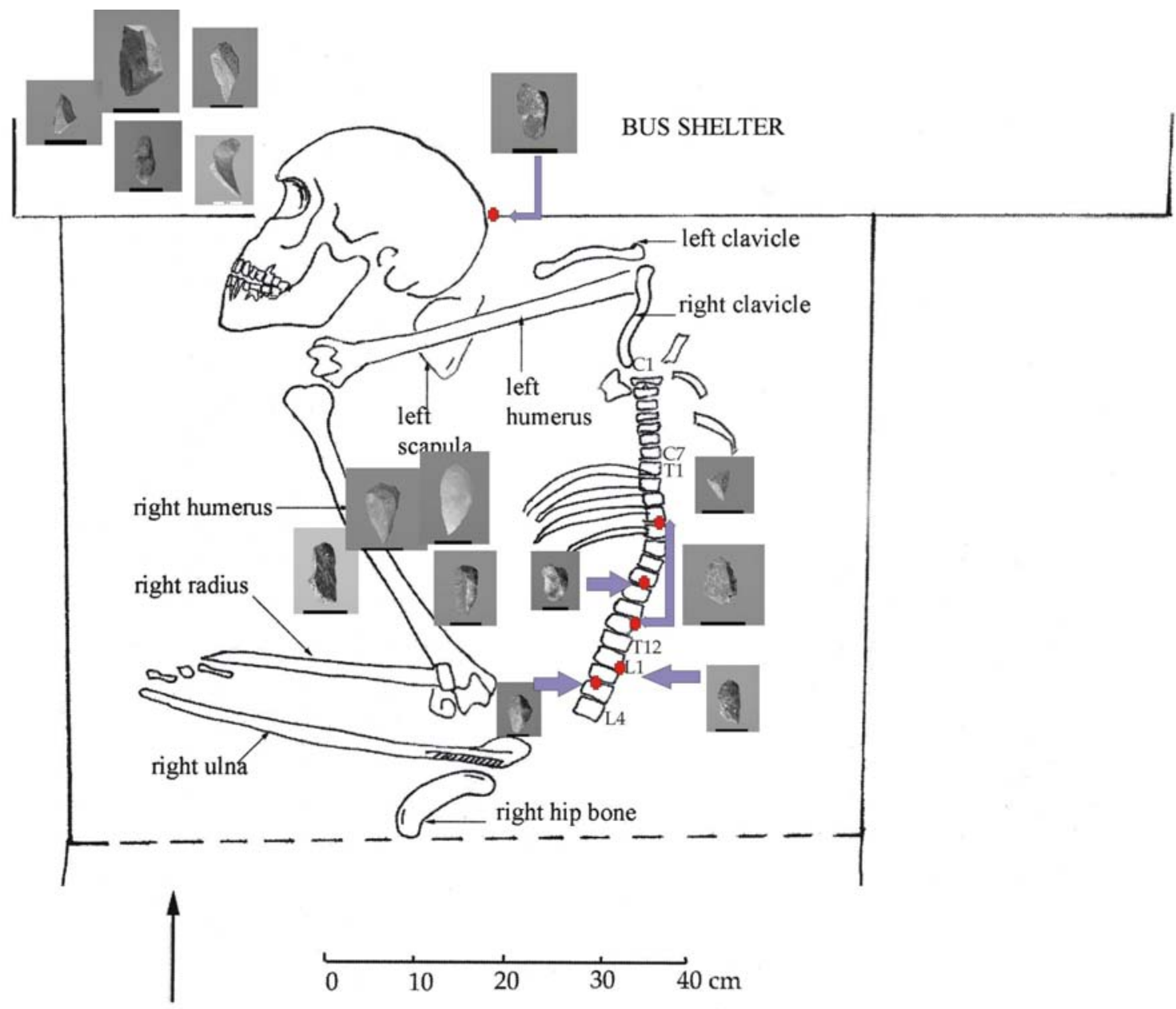

Figure 1. Schematic diagram of the upper torso and the location of the backed artefacts associated with the skeleton. The head has moved approximately $40 \mathrm{~cm}$ away from the vertebral column; however the mandible is still articulated. Dots on the spinal column indicate the location of the lodged backed artefacts (arrowed) and the placement of the other images indicates schematically the locations in which the artefacts were found (Reproduced from Antiquity [McDonald et al. 2007:879, Figure 1] with permission).

damage to the body of L2 and minor but unhealed damage to the body of L3 (McDonald et al. 2007). The artefact has bone residue (similar in colour and structure to the human vertebra) embedded in cracks at the crushed tip. If it were a spear barb, tip or lacerator - the latter a term employed by Kim Akerman (pers. comm.) to describe fragments of stone designed to release from the haft like shrapnel to aggravate haemorrhaging and other internal injuries (rather than to hold a spear in the wound as a barb might function) - this artefact would have entered the body on the left hand side, just above the blade of the left hipbone, assuming the body was in normal anatomical position and a horizontal entry wound. This spear probably passed through the large and small intestines and came close to the left renal artery and vein, and possibly the aorta. Backed artefact OON14 (Figure 3) was found in the position of the (missing) spinous process of the 11th thoracic vertebra. A tiny fragment (OON15, Figure 4) that refits to OON14 was later found in the vertebral canal of another thoracic vertebra (T4). Another backed artefact, OON16 (Figures 1 and 3), was found near L1 although this does not appear to have damaged the bone. Given their positions, these two artefacts (OON14 and 16) are likely to have been part of a spear that entered the back of the individual from the rear.

The artefacts were grouped in four areas around the skeleton (Figure 1): six stone artefacts (OON1, 11, 14+15, 16 and 17) found near the vertebral column; four (OON5, 







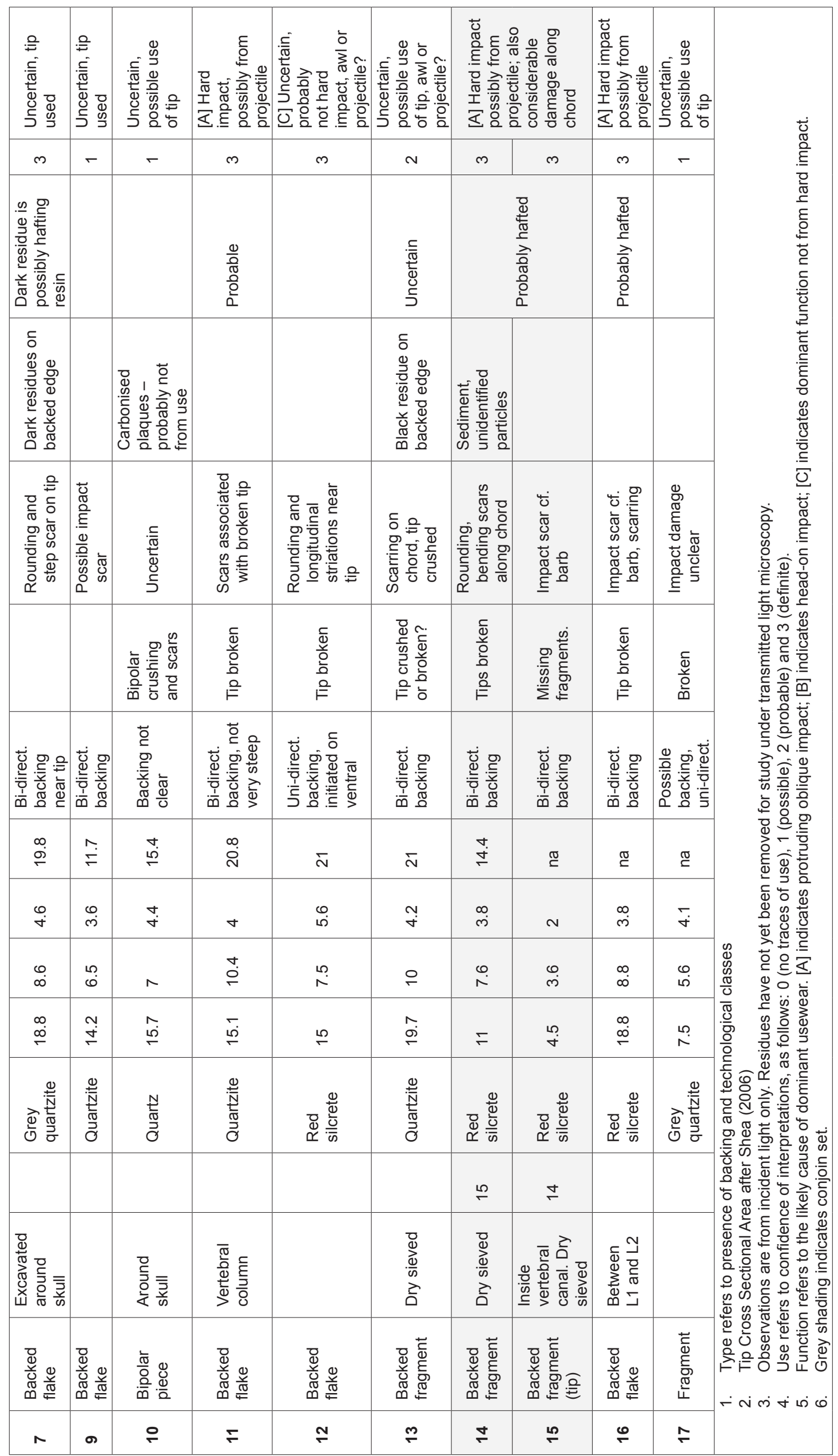



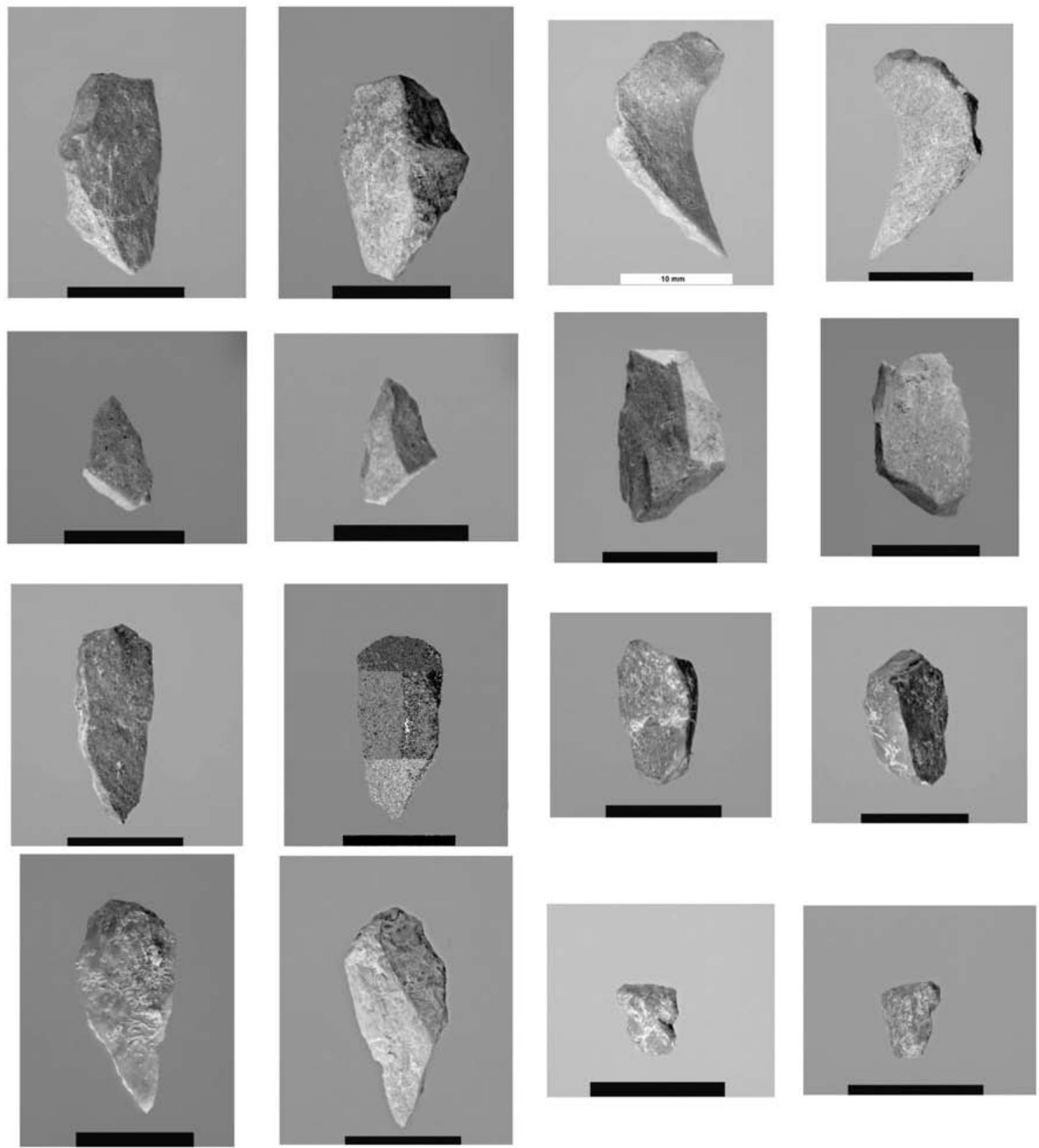

Figure 2. Both sides of artefacts OON1 to 8 (in sequence from upper left to right, and down the page) (scale bar $=1 \mathrm{~cm})$.

9,12 , and 13) were found near the right arm (humerus); five (00N2, 3+4, 7 and 10) were found near the front of the skull, and two $(00 \mathrm{~N} 6+8)$ were found just behind and underneath the skull.

A total of 17 stone artefacts including three conjoin sets (Figures 4-6; Table 1) were found, resulting in 14 near complete artefacts. Of these, twelve have clear backing retouch and two others (OON10 and 17) have indistinct edge crushing, which may also be the result of deliberate backing retouch.

\section{STONE PROJECTILES, POINTS, LACERATORS AND BARBS}

Archaeological evidence for, and diagnostic indicators of, projectile tips have been important in tracking hunting technology and modern human evolution (Shea 2006). Diagnostic use-wear traces have been reported on experimental stone tipped arrows and spears (e.g. Boot 2005; Dockall 1997; Fischer et al. 1984; Lombard 2005; Odell 2004: 178-9; Odell and Cowan 1986). Dockall (1997) reviews the range of impact breaks, macrowear, and microwear that have been considered 

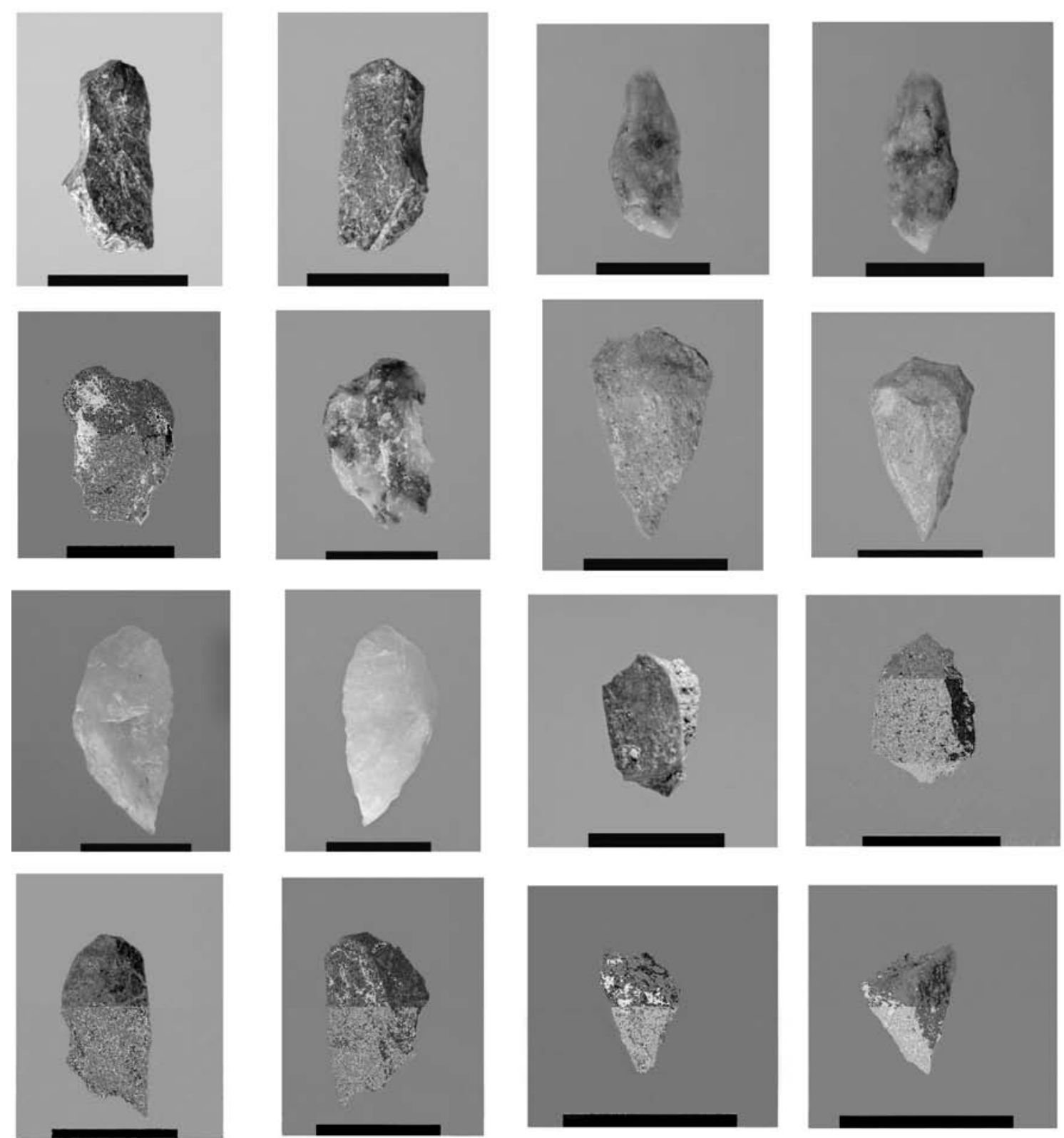

Figure 3. Both sides of artefacts OON9 to 17 (in sequence from upper left to right, and down the page). Note that the tiny fragment OON15 (which refits tip the tip of OON14) is excluded $($ scale bar $=1 \mathrm{~cm})$.

diagnostic either alone or in combination with other traces of use such as linear polish, striae, edge rounding, longitudinal macroscars, lateral macroscars, distal breaks, distal crushing and spin-off factures. Using these categories, we provide a summary of the traces found on the Narrabeen artefacts (Table 2). Longitudinal macroscars and lateral macroscars were not found on these small backed artefacts. Step and feather terminated bending scars occurred along the backed margins of several artefacts, indicating head-on and oblique impact, depending on the force producing the fractures (Figure 5). Neither microscopic linear streaks of polish or 'MLIT' (Fischer et al. 1984; van Gijn 1990:45-46) nor edge rounding were distinctly visible on any artefacts with diagnostic impact damage, but this was perhaps because of the grainy stone material. However, rounding and weakly developed polish was observed on the tip of OON2 (Figure 6), the chord of OON14 (Figure 7) and near the tip of OON12 (Figure 8). Linear striations were also very rare and only visible at high magnification in the form of possible scratches on quartz crystals. Rounding was visible on the fragile tip of OON2 as well as OON7, 12 and 14.

Distal crushing and breaks were both common, the latter occurring mostly in the form of scars with bending initiations and step or feather terminations along an arris or main edge of the 


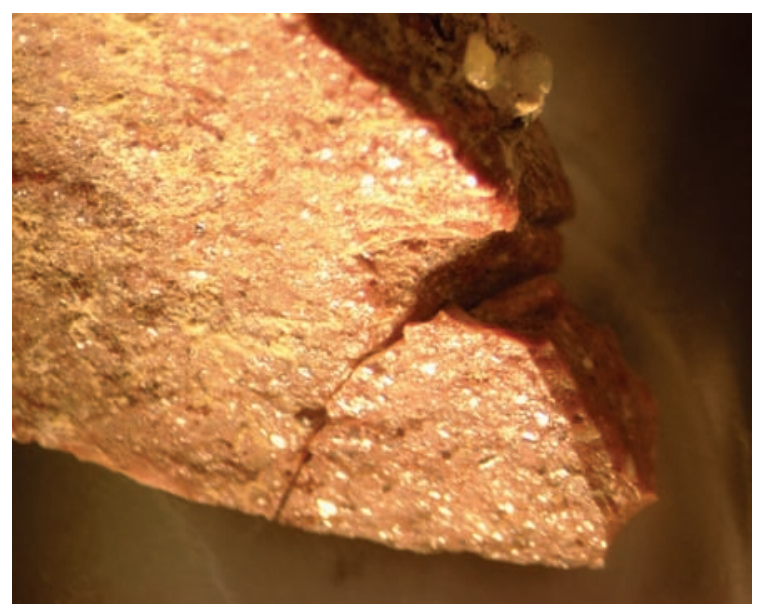

Figure 4. Detail of conjoin OON14 and 15, showing narrow feather terminating bending scar down the backed edge. backed margin (Table 2). Spin off fractures that appear to be initiated from the bending scars snapped from the tips were common (e.g. Figure 9), and are thought by Fischer et al. (1984) and Lombard (2005) to be a diagnostic impact fracture on points hafted as arrows or spears. It is uncertain whether the small robust backed artefacts (as in the Narrabeen assemblage) will break in quite the same way, although it seems likely. Further experiments are needed, particularly to model variables such as the effect of hafting arrangements and impact forces. Proximal damage was also rare and less marked than distal damage near the tips.

Few distinctive residue structures or films were observed directly on the artefacts or in extractions after aqueous sonication (Table 1). Embedded in cracks on some artifacts were fragments similar in colour and structure to bone; and on the backed edges of some artefacts there are dark, opaque smears (thought to be resin). Cellulose fibres and starch were noted on OON2. Presumably the open sandy environment was inimical to survival of blood and other tissues.

Table 2. Wear traces found on the Narrabeen artefacts. STBS back: step terminated bending scar on the backed surface; FTBS back: feather terminated bending scar on the backed surface. Artefact numbers with ' $*$ ' indicate that backing retouch is not distinct. No longitudinal macroscars or lateral macroscars were observed (cf. Dockall 1997)

\begin{tabular}{|c|c|c|c|c|c|c|c|c|}
\hline No. & $\begin{array}{c}\text { Find } \\
\text { Location }\end{array}$ & $\begin{array}{l}\text { Linear } \\
\text { polish }\end{array}$ & Striae & $\begin{array}{c}\text { Edge } \\
\text { rounding }\end{array}$ & $\begin{array}{c}\text { Distal } \\
\text { breaks }\end{array}$ & $\begin{array}{c}\text { Distal } \\
\text { crushing }\end{array}$ & $\begin{array}{l}\text { Spin-off } \\
\text { factures }\end{array}$ & $\begin{array}{l}\text { Proximal } \\
\text { damage }\end{array}$ \\
\hline 1 & Spine & - & $?$ & - & $\begin{array}{l}\text { STBS } \\
\text { back }\end{array}$ & - & - & \\
\hline 2 & Skull front & $x$ & $?$ & $x$ & - & - & - & \\
\hline $3-4$ & Skull front & - & - & - & $\begin{array}{l}\text { STBS } \\
\text { back }\end{array}$ & $x$ & $x$ & \\
\hline 5 & $\begin{array}{c}\text { Right } \\
\text { humerus }\end{array}$ & - & - & - & $\begin{array}{l}\text { STBS } \\
\text { back }\end{array}$ & $x$ & - & \\
\hline $6-8$ & Skull back & - & - & - & $\begin{array}{l}\text { STBS } \\
\text { lateral }\end{array}$ & $x$ & $x$ & \\
\hline 7 & Skull front & - & - & $x$ & $\begin{array}{l}\text { Step? } \\
\text { lateral }\end{array}$ & $x$ & - & $x$ \\
\hline 9 & $\begin{array}{c}\text { Right } \\
\text { humerus }\end{array}$ & - & - & - & $\begin{array}{l}\text { Steps } \\
\text { back }\end{array}$ & $x$ & $x$ & - \\
\hline $10^{*}$ & Skull front & - & - & - & FTBS & $x$ & - & $x$ \\
\hline 11 & Spine & $?$ & - & - & $\begin{array}{l}\text { STBS } \\
\text { back }\end{array}$ & - & $x$ & \\
\hline 12 & $\begin{array}{c}\text { Right } \\
\text { humerus }\end{array}$ & $?$ & $x$ & $x$ & snap & $x$ & - & - \\
\hline 13 & $\begin{array}{c}\text { Right } \\
\text { humerus }\end{array}$ & - & - & - & - & $?$ & - & - \\
\hline $\begin{array}{l}14- \\
15\end{array}$ & Spine & $?$ & - & $x$ & $\begin{array}{l}\text { FTBS } \\
\text { back }\end{array}$ & - & $x x$ & $x$ \\
\hline 16 & Spine & - & - & - & $\begin{array}{l}\text { STBS } \\
\text { back }\end{array}$ & - & $x$ & - \\
\hline $17^{*}$ & Spine & - & - & - & $?$ & $?$ & - & $?$ \\
\hline
\end{tabular}




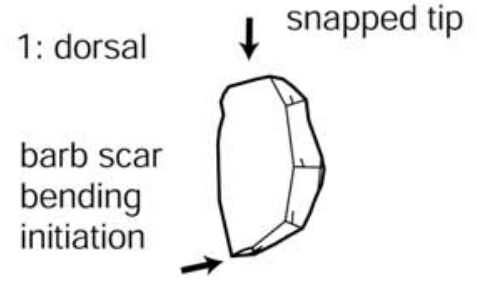

5: dorsal

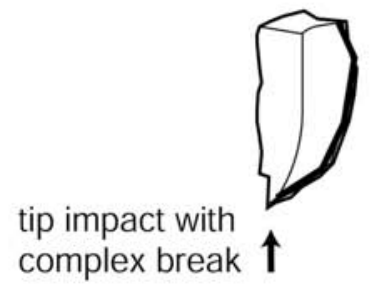

7: dorsal

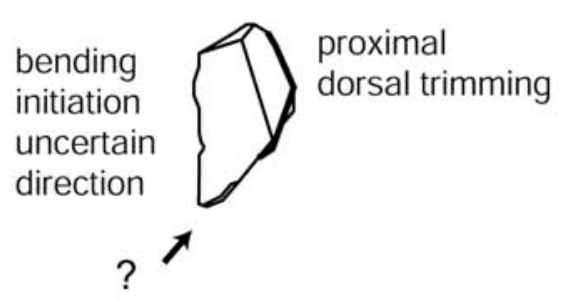

11: dorsal

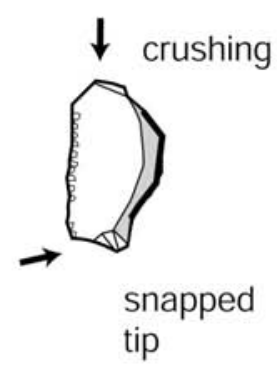

14: orientation?

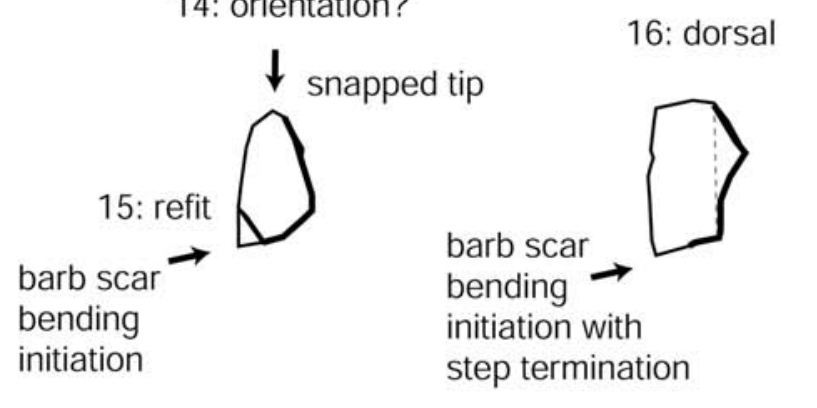

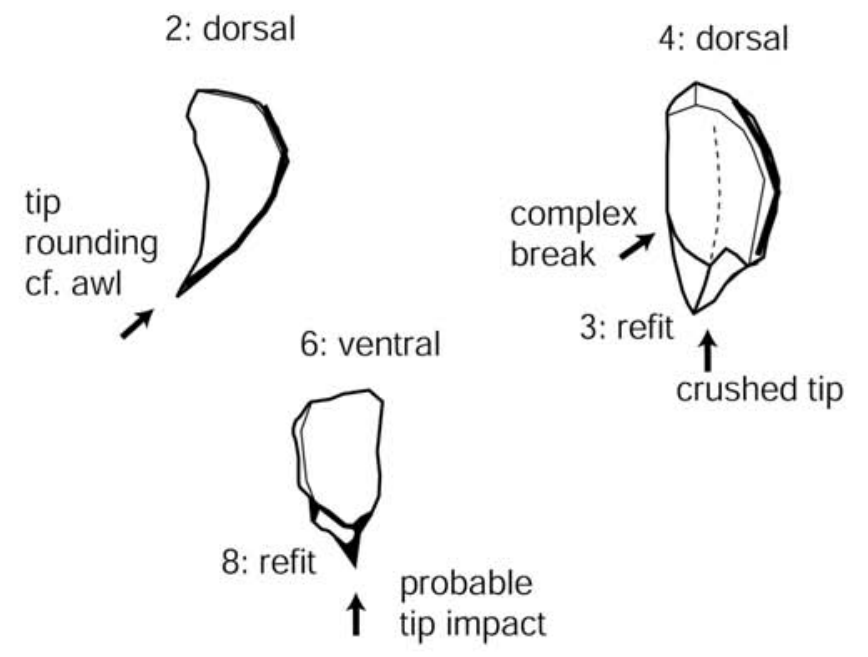

9: dorsal

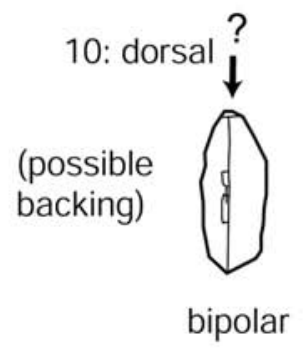

13: orientation?
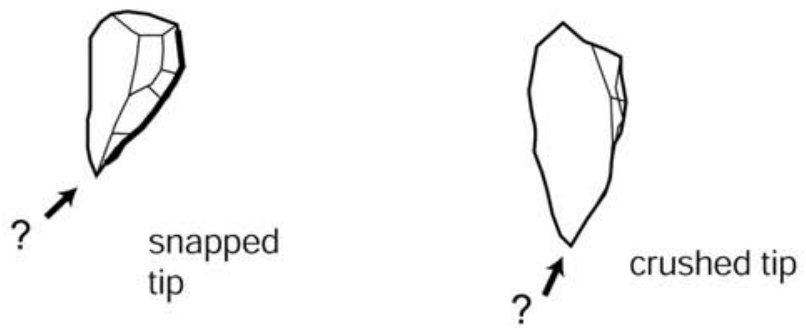

17: orientation?

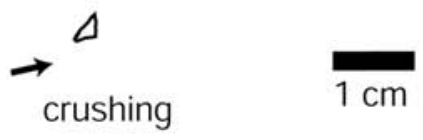

Figure 5: Narrabeen artefacts showing suggested impact direction and breaks.

All illustrations have proximal ends up and backed edges to the right except 6 . which has the backed edge to the left. 


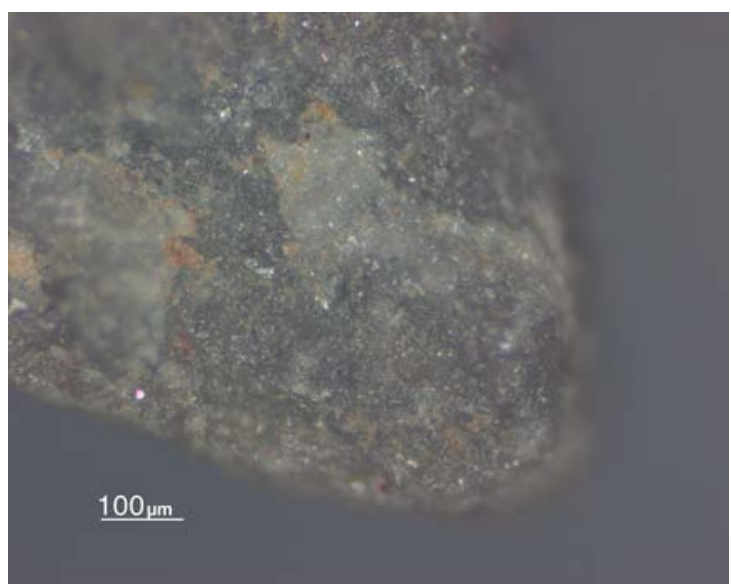

Figure 6: Microwear on the fragile tip of OON2, with marked rounding and polish indicating function as a skin working implement (awl).

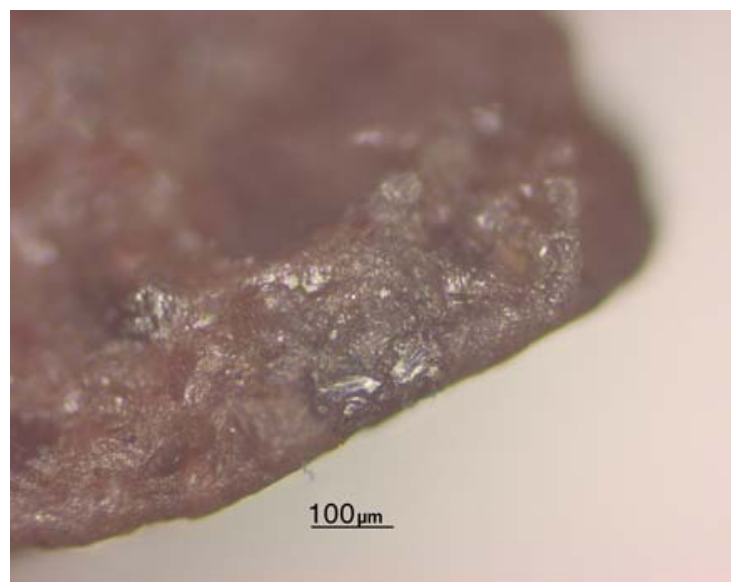

Figure 8: Rounding and faint striations near the tip of OON12.

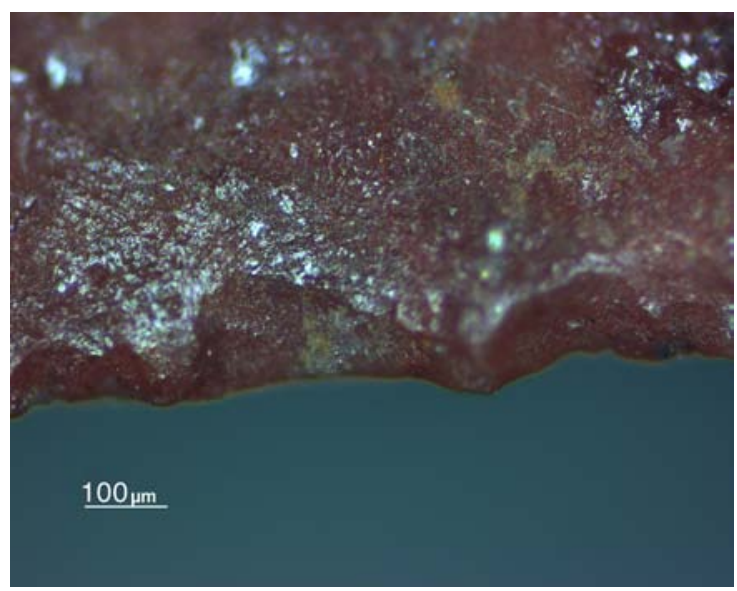

Figure 7: Edge scarring and rounding on the chord of OON14.

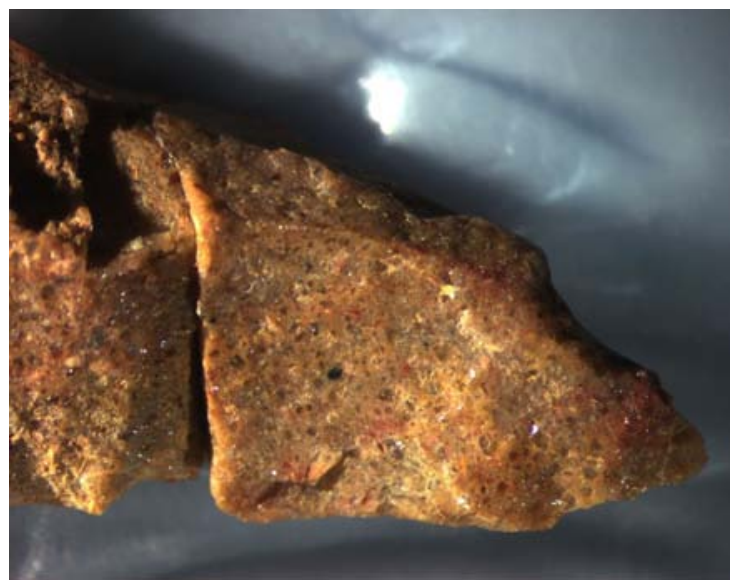

Figure 9. Tip break of $\mathrm{OON} 3+4$, showing a long narrow fracture with a step termination that initiates a spin off fracture (with step termination).

\section{DISCUSSION}

Possible hafting arrangements (see Figure 10), given the fractures and wear traces, must account for hard impact on small asymmetric stone artefacts which have hafting traces in the form of dark smears similar to resin, and rounding along the backed edge. Such weapons, armed with lithic barbs, lacerators or tips, might have been thrown (e.g. spears), stabbed (e.g. spears or knives) or swung (e.g. clubs). The wear traces are all consistent with use as hafted elements of spears, knives or even 'barbed' clubs (i.e. clubs studded with backed artifacts). Ethnographic, experimental and contextual evidence indicate that spears and knives are likely. For example, OON1 is most likely to be from a spear simply because of the penetration requirements from left hip to spine. Conjoined artefacts OON14 and 15 together with OON16 could be from one or more spears or stabbing knives.

The absence of distinctive wear along the backed edge and the proximal end of each flake suggests that the backed artefacts were not firmly slotted into wooden or bone handles, which might be expected for reliable use as a knife or club, although 'taap' saw- knives restricted to southwest Western Australia were probably used for general butchering. However, these were 'resin hafted' and not slotted into their wooden handles (Kamminga 1982:32). On the other hand, ethnographic data (e.g. Akerman et al. 2002) show that stone lacerators and tips may be deliberately set in resin 


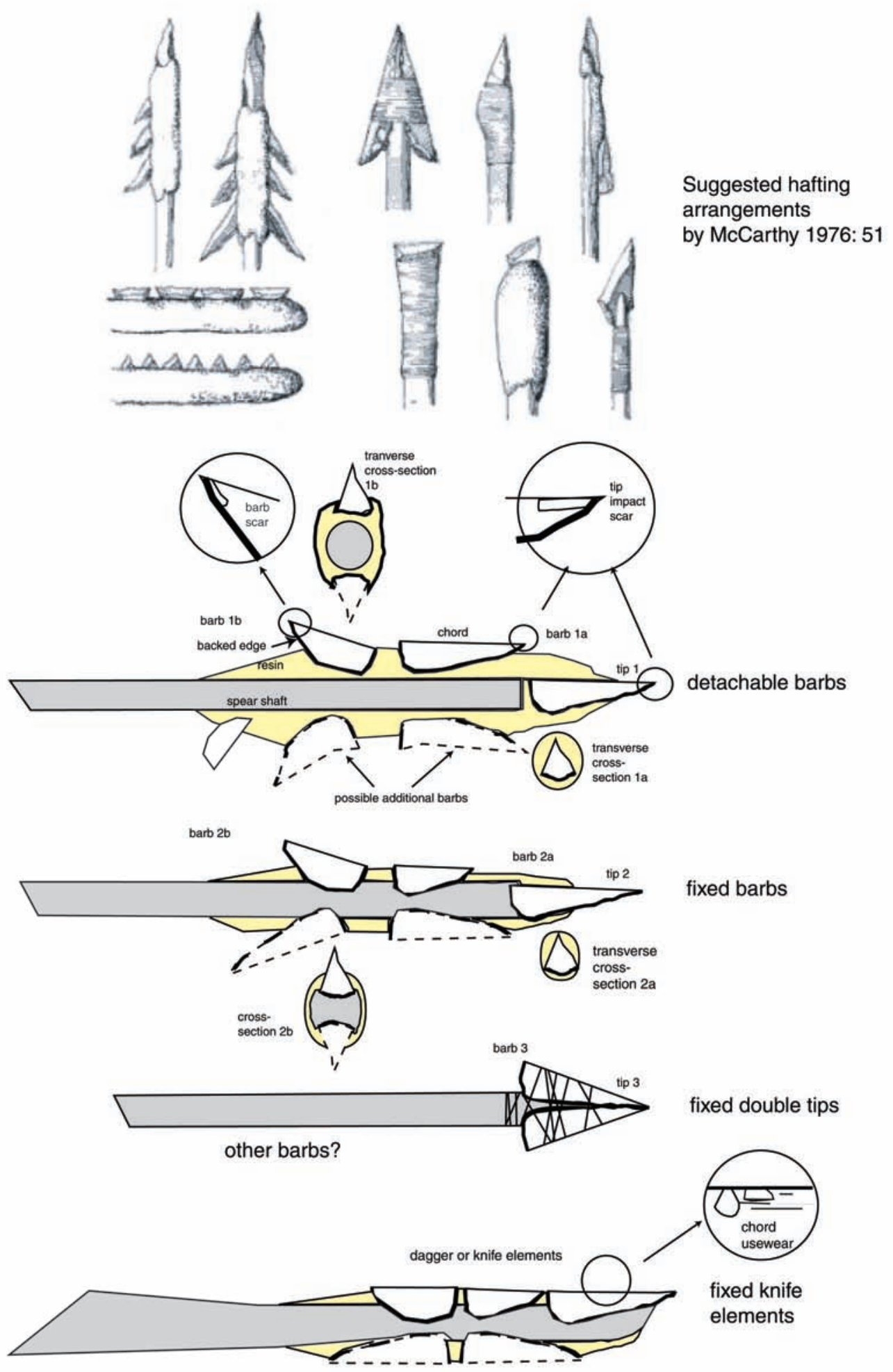

Figure 10. Possible hafting arrangements of backed artefacts. McCarthy's suggested hafting arrangements reproduced with permission from The Australian Museum.

away from direct contact with the spear shaft, so that the chipped stones could easily detach on impact (Akerman 1978). Kim Akerman (pers. comm. April 15th 2007) suggested that the effect of multiple detachable lacerators would be similar to the effect of shrapnel wounds. Several Narrabeen artefacts have edge rounding and other use-wear on the chord indicating use as knives, and there is one awl. Small stones including awls, edge elements of knives and other tools could have been 
re-cycled as lacerators, in much the same way as the stone chips of the ethnographically known death spear (e.g. Dortch 1984:53; see also an illustration of a death spear [Collector : Unknown (A4932)] on the South Australian Museum Website, 2007). It is also possible that detachable fore shafts (with firmly attached backed artefacts) might have been removed from spears and used for a variety of tasks including butchery, despite their primary function as projectile heads (see also the description by Davidson (1934:61) of reed shafts with (detachable?) hardwood heads armed with stone flakes).

\section{CONCLUSION}

The skeletal injuries, penetration depth, distribution of fragments and use-wear indicate a minimum of three weapons, and probably more, were used in the slaying of the Narrabeen man. Substantial proximal (tip) damage and spin off fractures thought to be diagnostic of projectile impact are found on artefacts in all find locations (skull - front and back, spine and right humerus), suggesting a minimum of three spears. Six artefacts may be barbs, lacerators or tips with spin-off fractures (depending on the possible orientation and hafting arrangements). These six indicate the maximum number of possible high impact contacts (e.g. with bone). If we assume that only the initial impact of each spear with the victim is likely to result in such damage (to lacerators, barbs or tips), then up to six spears each armed with one tip and two or three barbs or lacerators seems a likely configuration. Of course, there are many assumptions involved in such reconstructions, and we have outlined the logic of some possibilities. Trying to test and evaluate each possibility is fraught with difficulty, and Tom Loy (to whom this volume is dedicated, and who kept revising elements of Ötzi's alpine mummy mystery) would be familiar with such unfinished stories! We are planning further experimental work to evaluate likely hafting arrangements.

The Narrabeen artefacts provide the first Australian archaeological evidence of backed artefacts used for fighting, payback killing or other human violence, as distinct from hunting game, as commonly inferred (Kamminga 1980; McBryde 1985, 1986; McCarthy 1976). If the Narrabeen artefacts were recycled tools and hafted in similar fashion to the stone lacerators of the death spear, this evidence may also be consistent with the wide range of functions identified recently by Robertson (2005), Fullagar et al. (1994) and McDonald et al. (1994). The timing of this mid-Holocene occurrence of payback or other killing correlates with a widespread proliferation of backed artefacts in the archaeological record, particularly in south-eastern Australia (Hiscock \& Attenbrow 2005a, 2005b; Jo McDonald Cultural Heritage Management 2005). While the slaying of the Narrabeen man may be related to climate change, increased stress, shifts in subsistence and settlement and an increased social proscription, it seems less and less likely that backed artefacts as a class have a dominant primary function. They appear to have been used for many purposes in different times and places. We have demonstrated here that one of these functions was as detachable lacerating elements of death spears.

\section{ACKNOWLEDGEMENTS}

We thank the Editors and Symposium organisers for the opportunity to present these results. We thank Allan Madden of the Metropolitan Local Aboriginal Land Council for his continued interest in this research and permission to publish details pertaining to the Narrabeen man's remains. We also thank several anonymous referees, as well as Annie Ross, Veerle Rots, Val Attenbrow, and also Kim Akerman for his specific comments on barbs, lacerators and hafting arrangements. The authors acknowledge both the facilities and scientific and technical assistance from the staff in the Australian Key Centre for Microscopy and Microanalysis Research Facility (AMMRF) and the Australian Key Centre for Microscopy and Microanalysis at the University of Sydney. 


\section{REFERENCES}

Akerman, K. 1978. Notes on the Kimberley stone-tipped spear, focusing on the hafting mechanism. Mankind 11(4): 486.

Akerman, K., R. Fullagar and A. van Gijn 2002. Weapons and wunan: production, function and exchange of spear points from the Kimberley, northwestern Australia. Australian Aboriginal Studies 1:13-42.

Boot, P. 2005. Transverse snapping on stone artefacts. In I. McFarlane, M.J. Roberts and R. Paton (eds.) Many Exchanges: Archaeology, History, Community and the Work of Isobel McBryde, pp. 343-366. Canberra: Aboriginal History Monograph..

Davidson, D.S. 1934. Australian spear-traits and their derivations. Journal of the Polynesian Society 43(1):41-72.

Dockall 1997. Wear traces and projectile impact: a review of the experimental and archaeological evidence. Journal of Field Archaeology 24(3): 321-331.

Dortch, C. 1984. Devil's Lair, A Study in Prehistory. Perth: Western Australian Museum.

Fischer, A., P.V. Hensen and P. Rasmussen 1984. Macro and micro wear traces on lithic projectile points. Journal of Danish Archaeology 3:19-46.

Fullagar, R., J. Furby and L. Brass 1994. Stone artefacts from Bulga, Hunter valley. Unpublished report for M. Koettig. [Fullagar, R., J. Furby and L. Brass 1994. Use-wear and residue analysis of stone tools from Bulga. In Bulga Lease Authorisation 219 salvage excavations. A report to Saxonvale Coal Pty Ltd, by M. Koettig, Vol. 5, pp. 26-105].

Hiscock, P. and Attenbrow V. 2005a. Reduction continuums and tool use. In C. Clarkson \& L. Lamb 2005. (eds) Lithics Down Under: Recent Australian Approaches to Lithic Reduction, Use and Classification, pp. 43-55. BAR International Monograph Series S1408. Oxford: Archaeopress..

Hiscock, P. and V. Attenbrow 2005b. Australia's Eastern Regional Sequence revisited: technology and change at Capertee 3. BAR International Monograph Series 1397. Oxford: Archaeopress.

Jo McDonald Cultural Heritage Management 2005. Salvage Excavation of Six Sites along Caddies, Second Ponds, Smalls and Cattai Creeks in the Rouse Hill Development Area, NSW. Australian Archaeological Consultancy Monograph Series, Volume 1 [Available online: http://www.aacai.com.au/monograph/index.html].

Kamminga, J. 1980 A functional investigation of Australian microliths. The Artefact 5:1-18.

Kamminga, J. 1982. Over the Edge. Functional Analysis of Australian Stone Tools. Occasional Papers In Anthropology 12. St Lucia: Anthropology Museum, University of Queensland.

Lombard, M. 2005. A method for identifying stone age hunting tools. South African Archaeological Bulletin 60(182):115-120.

McBryde, I. 1985. Backed blade industries from the Graman rock shelters, New South Wales: some evidence on function, in V. N. Misra and P. Bellwood (ed.) Recent advances in IndoPacific Prehistory, pp. 231-249. New Delhi: Oxford and IBH Publishing.

McBryde, I. 1986. The broken artefact and functional studies. In G. Ward (ed.) Archaeology at ANZAAS, Canberra, pp.203-209Canberra: Canberra Archaeological Society. 
McCarthy, F. 1976. Australian Aboriginal Stone Implements, Including Bone, Shell and Tooth Implements. Sydney: The Australian Museum Trust.

McDonald, J., Rich, E., and Barton, H. 1994 The Rouse Hill Infrastructure Project (Stage 1) on the Cumberland Plain, western Sydney. In M.E. Sullivan, S. Brockwell and A. Webb (eds) Archaeology in the North: Proceedings of the 1993 Australian Archaeological Association Conference, pp. 259-293. Darwin: North Australian Research Unit, Australian National University.

McDonald, J. D. Donlon, J. Field, R. Fullagar, J. Brenner Coltrain, P. Mitchell and M. Rawson 2007. The first archaeological evidence for death by spearing in Australia. Antiquity 81:877885.

Odell, G. 2004. Lithic Analysis. New York: Kluwer Academic/Blackwell.

Odell, G. H. and F. Cowan 1986. Experimentation with spears and arrows using animal targets. Journal of Field Archaeology 13:195-212.

Robertson, G. R. 2005. Backed artefact use in Eastern Australia: a residue and use-wear analysis. Unpublished PhD thesis. St Lucia: School of Social Science, The University of Queensland.

Shea J. 2006. The origins of lithic projectile point technology: evidence from Africa, the Levant, and Europe. Journal of Archaeological Science 33 (6):823-846.

South Australian Museum Website [URL: http://www.samuseum.sa.gov.au/ngurunderi/ng6htm. htm; Accessed May 2007].

van Gijn, A. L. 1990 The wear and tear of flint: principles of functional analysis applied to Dutch Neolithic assemblages. Analecta Praehistorica Leidensia 22. 